\title{
Analisis Politik Hukum Dan Implementasinya
}

\author{
Islamiyati, ${ }^{1}$ Dewi Hendrawati ${ }^{1}$ \\ Fakultas Hukum Universitas Diponegoro \\ JL. Prof. Sudharto No. 1 Semarang, Jawa Tengah, 50275 \\ Islamiyati@yahoo.co.id
}

\begin{abstract}
The relationship between politics and law is very familiar, law is a legislation that is actually a crystallization of political wills that interact and influence each other. Political law is defined as the official line of state policy to create and enact legislation in order to achieve the goals and goals of the state as contained in the preamble of the Constitution of 1945 alenia IV. Implementation of legal politics in the form of legislation that is used as a tool to achieve state goals, in accordance with the national legal framework of national law, which can be seen in PROLEGNAS AND PROLEGDA.
\end{abstract}

Keyword: law, politics, implementation.

\begin{abstract}
ABSTRAK
Hubungan antara politik dan hukum sangat akrab, hukum merupakan peraturan perundangundangan yang sebenarnya adalah kristalisasi dari kehendak-kehendak politik yang saling berinteraksi dan saling mempengaruhi. Politik hukum diartikan sebagai garis resmi kebijakan negara untuk membuat dan menetapkan peraturan perundang-undangan guna mencapai cita-cita dan tujuan negara seperti yang terdapat pada pembukaan UUD NRI 1945 alenia IV. Implementasi politik hukum berupa ditetapkannya perundang-undangan yang digunakan sebagai alat untuk mencapai tujuan negara, yang sesuai dengan kerangka dasar politik hukum nasional, yang dapat dilihat di PROLEGNAS DAN PROLEGDA.
\end{abstract}

Kata Kunci: hukum, politik, implementasi.

\section{PENDAHULUAN}

Hukum merupakan seperangkat aturan yang mengatur kehidupan manusia di masyarakat. Hukum tidak bekerja sendirian, tetapi membutuhkan studi ilmu lain supaya dapat mencapai tujuannya. Bekerjanya hukum selalu dipengaruhi oleh subsistem-subsistem lain, seperti; politik, sosial, ekonomi, budaya, dan lainnya. Menurut teori Talcott Parsons, menjelaskan bahwa hukum adalah salah satu subsistem dalam sistem sosial yang sangat 
besar, subsistem tersebut adalah budaya, politik dan ekonomi. Tugas hukum menata keserasian dan gerak sinergis subsistem lainnya, termasuk politik. ${ }^{2}$

Hubungan antara politik dan hukum sangat akrab, politik selalu melakukan interverensi dalam pembuatan dan pelaksanaan hukum, sehingga antara politik dan hukum mempunyai hubungan yang saling mempengaruhi. Hukum dipandang sebagai dependent variable (variabel terpengaruh) dan politik diletakkan sebagai independent varable (variabel berpengaruh). ${ }^{3}$ Hal ini berarti, bahwa hukum yang merupakan peraturan perundangundangan yang ditetapkan oleh badan legeslatif, sebenarnya adalah kristalisasi dari kehendak-kehendak politik yang saling berinteraksi dan saling mempengaruhi. Kehendak politik merupakan manifestasi dari keadaan masyarakat yang sedang berlangsung, bisa jadi berasal dari masyarakat atau penguasa negara.

Dengan demikian hukum terbentuk dan berubah sesuai dengan keadaan dan perkembangan masyarakat, bahkan hukumpun bisa mengubah masyarakat. Hukum akan selalu menyertai kehidupan masyarakat di manapun dan kapanpun. Cicero (106-43 SM), seorang filsuf Romawi menyatakan Ubi Societas ibi ius, artinya di mana ada masyarakat, di sana ada hukum. ${ }^{4}$ Kehidupan masyarakat, tentunya sarat dengan kepentingan-kepentingan politik yang akan mempengaruhi pembuatan dan keputusan hukum. Lalu, sejauhmanakah politik mempengaruhi bekerjanya hukum?, sehingga kebijakan politik akan mempengaruhi terbentuknya hukum. Pertanyaan inilah yang memunculkan istilah politik hukum.

Istilah politik hukum berbeda dengan politik dan hukum. Politik hukum selalu berbicara tentang perwujudan tujuan-tujuan ideal hukum, hukum tidak boleh dimanfaatkan untuk tujuan selain tujuan ideal bersama dari suatu masyarakat, bangsa dan negara. Oleh karena itu hukum diakui sebagai milik bersama, tidak boleh dijadikan sebagai alat oleh pihak tertentu atau kepentingan tertentu. Pada politik hukum, hukum ditugaskan mengemban misi suatu masyarakat untuk mewujudkan visi yang dituju oleh masyarakat tersebut. ${ }^{5}$

\footnotetext{
${ }^{2}$ Bernard L. Tanya, Ed. All, Teori Hukum (Strategi tertib Manusia Lintas Ruang dan Generasi), Yogyakarta, Genta Publishing, 2010, hal. 152-153.

${ }^{3}$ Mahfud MD, Politik Hukum Di Indonesia, Rajawali Pers, Jakarta, 2009, hal. 9.

${ }^{4}$ Stephen W. Ball, Bibliographical Essay / Legal Positivism, Natural Law, and the Hart/Dworkin Debate, Journal of Criminal Justice Ethics, University of California, San Diego, ISSN: 0731-129X (Print) 1937-5948 (Online) Journal homepage: http://www.tandfonline.com/loi/rcre20, hal. 68, upload at 29 June 2016, At: 12:35 WIB. Adji Samekto, Pergeseran Pemikiran Hukum dari Era Yunani Menuju Postmodernisme, Jakarta, Konpress, 2015, hal. v.

${ }^{5}$ Bernard L. Tanya, Politik Hukum, Agenda Kepentingan Bersama, Op. Cit., hal. 4-5.
} 
Istilah politik dan hukum selalu terfokus pada real politik dan hukum, artinya realitas hubungan timbal balik dan tarik menarik antara politik dan hukum. ${ }^{6}$ Dinamika interaksi antara politik dan hukum, menjadi kajian menarik dalam kajian sosiologi, sosiologi hukum dan politik. Pada kajian ini, posisi hukum bisa dijadikan alat atau kendaraan dalam berpolitik yang notabene untuk mencapai tujuan yang diinginkan oleh pihak-pihak tertentu guna menguasai pihak yang lain. Hukum dijadikan sebagai media untuk meraih kekuasaan, bukan mewujudkan tujuan yang diinginkan oleh hukum.

Pada makalah ini akan diuraikan tentang arti politik hukum dan implementasinya di Indonesia. Tujuannya untuk menguraikan dan menganalisis pemahaman politik hukum beserta ruang lingkupnya, tujuan dan manfaat politik hukum nasional beserta implementasnya. Manfaat penulisan makalah ini adalah dapat dipahami dan dianalisis politik hukum dan implementasi politik hukum di Indonesia

\section{PEMBAHASAN}

Pada pembahasan ini, akan diuraikan tentang arti politik hukum beserta ruang lingkupnya, tujuan dan manfaat politik hukum nasional beserta implementasnya.

\section{Arti Politik Hukum}

Politik hukum berasal dari kata politik dan hukum, politik artinya usaha menggapai kehidupan yang lebih baik, atau usaha untuk menentukan peraturan-peraturan yang dapat diterima oleh masyarakat untuk membawa ke arah kehidupan bersama yang harmonis. ${ }^{7}$ Sedangkan hukum diartikan sebagai aturan perundang-undangan yang ditetapkan oleh pemerintah, dan mengandung sanksi apabila dilanggar. ${ }^{8}$ Politik hukum berarti kebijakan negara untuk mencapai tujuannya melalui pembentukan perundang-undangan. Status hukum yang berarti undang-undang berfungsi untuk menyelesaikan permasalahan negara. Oleh karena itu negara berupaya membuat dan menetapkan perundang-perundangan supaya tujuan negara tercapai. Negara di sini adalah lembaga legeslatif yang berwenang menetapkan perundang-undangan setelah disetujui oleh lembaga eksekutif yakni presiden.

\footnotetext{
${ }^{6}$ Ibid, hal. 7.

${ }^{7}$ Miriam Budiardjo, Dasar-Dasar Ilmu Politik, Jakarta, Gramedia Pustaka Utama, 2009, hal. 15.

${ }^{8}$ Penulis menggunakan konsep hukum positivisme, karena kajian hukum dalam politik hukum, diarahkan pada hukum sebagai aturan yang terdapat dalam perundang-undangan. Theo Huijbers, Filsafat Hukum, Yogyakarta, PT. Kanisius, 2009, hal. 33
} 
Politik hukum juga bisa dijelaskan sebagai "garis resmi" yang ditetapkan negara guna mencapai tujuan negara melalui hukum.

Pengertian politik hukum, telah dikemukakan oleh beberapa ahli, berikut ini akan dijelaskan beberapa pengertian politik hukum dari beberapa ahli hukum dan politik, yakni :

a. Menurut Mahfud MD, menjelaskan bahwa bahwa politik hukum diartikan sebagai legal policy (kebijakan hukum) yang akan atau telah dilaksanakan oleh pemerintah. Politik hukum ini mencakup pembuatan hukum yang berintikan pembuatan dan pembaharuan terhadap materi-materi hukum agar dapat disesuaikan dengan kebutuhan, dan pelaksanaan ketentuan hukum yang sudah ada, termasuk penegakan fungsi lembaga dan pembinaan para penegak hukum. ${ }^{9}$

b. Menurut Soedarto, menjelaskan bahwa politik hukum adalah usaha untuk mewujudkan peraturan-peraturan yang baik sesuai dengan keadaan dan situasi pada suatu waktu. ${ }^{10}$ Pengertian ini dapat dimaknai bahwa politik hukum merupakan upaya negara untuk mewujudkan hukum yang dijiwai dengan iktikad baik dan disesuaikan dengan kondisi masyarakat yang tengah berlangsung. Ini berarti menjadikan hukum sebagai kebutuhan masyarakat yang sangat diperlukan untuk mewujudkan tujuan negara, masyarakat dan bangsa.

c. Sunaryati Hartono berpendapat bahwa politik hukum adalah sebuah alat (tool) atau sarana dan langkah yang dapat digunakan oleh pemerintah untuk menciptakan sistem hukum nasional yang dikehendaki dan dengan sistem hukum nasional itu akan diwujudkan cita-cita bangsa Indonesia. ${ }^{11}$ Pendapat ini menjelaskan bahwa politik hukum dapat digunakan sebagai alat atau bahan untuk membuat sistem hukum nasional yang dikendaki guna mewujudkan cita-cita bangsa Indonesia yang sesuai dengan nilai-nilai yang terkandung dalam Pancasila, yakni nilai persatuan, keadilan sosial, kemanusiaan, kerakyatan dan Ketuhanan Yang Maha Esa. Faktor-faktor yang akan menentukan politik hukum tidak semata-mata ditentukan oleh apa yang kita citacitakan atau tergantung pada kehendak pembentuk hukum, praktisi atau para teoretisi belaka, akan tetapi ikut ditentukan pula oleh kenyataan serta perkembangan hukum di lain-lain negara serta perkembangan hukum internasional. Perbedaan politik hukum

\footnotetext{
${ }^{9}$ M. Mahfud MD, Politik Hukum di Indonesia, LP3ES, 1998, hal. 8.

${ }^{10}$ Soedarto, Hukum dan Hukum Pidana, Bandung, Alumni, 1986, hal, 151.

${ }^{11}$ Sunaryati Hartono, Politik Hukum Menuju Satu Sistem Hukum Nasional, Bandung, Alumni, 1991, hal. 1
} 
suatu negara tertentu dengan negara lain inilah yang kemudian menimbulkan apa yang disebut dengan Politik Hukum Nasional. ${ }^{12}$

d. Satjipto Rahardjo mendefinisikan bahwa politik hukum sebagai aktivitas memilih dan cara yang hendak dipakai untuk mencapai suatu tujuan sosial dan hukum tertentu dalam masyarakat. ${ }^{13} \mathrm{Hal}$ ini dapat dijelaskan kembali bahwa politik hukum merupakan aktifitas atau perilaku untuk memilih hukum dan cara yang hendak dipakai negara untuk memilih hukum guna mencapai tujuan sosial dan hukum tertentu dalam masyarakat.

e. Menurut Abdul Hakim Garuda Nusantara, menjelaskan bahwa politik hukum adalah kebijakan hukum (legal policy) yang hendak diterapkan atau dilaksanakan oleh suatu pemerintahan negara tertentu. ${ }^{14}$ Garuda Nusantara menjelaskan pula wilayah kerja politik hukum dapat meliputi pelaksanaan ketentuan hukum yang telah ada secara konsisten, proses pembaruan dan pembuatan hukum, yang mengarah pada sikap kritis terhadap hukum yang berdimensi ius contitutum dan menciptakan hukum yang berdimensi ius constituendum, serta pentingnya penegasan fungsi lembaga dan pembinaan para penegak hukum.

f. Menurut Padmo Wahyono, mengatakan bahwa politik hukum adalah kebijakan dasar penyelenggara negara dalam bidang hukum yang akan, sedang dan telah berlaku, yang bersumber dari nilai-nilai yang berlaku di masyarakat untuk mencapai tujuan negara yang dicita-citakan. Kata kebijakan di atas berkaitan dengan adanya strategi yang sistematis, terperinci dan mendasar serta berkaitan dengan pembentukan hukum, penerapan hukum dan penegakannya sendiri. ${ }^{15}$ Dalam merumuskan dan menetapkan hukum yang telah dan akan dilakukan, politik hukum menyerahkan otoritas legislasi kepada penyelenggara negara, tetapi dengan tetap memperhatikan nilai-nilai yang berlaku di masyarakat, semuanya diarahkan dalam rangka mencapai tujuan negara yang dicita-citakan. ${ }^{16}$

\footnotetext{
${ }^{12}$ Sunaryati Hartono, Op. Cit., hal. 23.

${ }^{13}$ Satjipto Raharjo, Ilmu Hukum, Bandung, Citra Aditya Bakti, 2000, hal. 35.

${ }^{14}$ Moh. Mahfud MD, Membangun Politik Menegakkan Konstitusi, Jakarta, Rajawali Pers, 2010, hal. 15

${ }^{15}$ Padmo Wahyono, Menyelisik Proses Terbentuknya Perundang-Undangan, Forum Keadilan, No. 29 April, 1991, hal. 65.

${ }^{16}$ Padmo Wahyono, Indonesia Negara berdasarkan Atas Hukum, Cet II, Jakarta, Ghalia Indonesia, 1986, hal. 160.
} 
Berdasarkan pemahaman politik hukum di atas, dapatlah disimpulkan bahwa politik hukum merupakan garis resmi kebijakan negara untuk membuat dan menetapkan peraturan perundang-undangan guna mencapai cita-cita dan tujuan negara seperti yang terdapat pada pembukaan UUD NRI 194 alenia IV. Politik hukum di Indonesia berbeda dengan politik hukum negara yang lain. Perbedaan ini disebabkan karena adanya perbedaan latar belakang kesejarahan, pandangan dunia (world-view), sosio-kultural, dan political will dari masing-masing pemerintah. ${ }^{17}$

Dengan demikian politik hukum perlu disesuaikan dengan jiwa bangsa (volkgeist) rakyat Indonesia, karena antara hukum dan watak atau karakter suatu bangsa terdapat hubungan organik. Hukum adalah cerminan dari volkgeist, karena itu harus dicari dan ditemukan melalui hukum yang hidup di masyarakat. Oleh karena itu tugas penting hukum, selain menetapkan aturan dalam bentuk perundang-undangan, juga menggali mutiara nilai hukum yang hidup di masyarakat. Hal ini sesuai dengan teori Savigny yang menkonstruksi hukum sebagai nilai yang hidup di masyarakat, sebagai jiwa bangsa (volkgeist), di tingkat lokal. ${ }^{18}$ Teori ini digunakan dalam pembahasan tujuan politik hukum di Indonesia.

Tujuan politik hukum adalah untuk memungkinkan peraturan hukum positif dirumuskan secara lebih baik dan untuk memberi pedoman, tidak hanya kepada pembuat UU, tetapi juga pengadilan yang menetapkan UU dan juga kepada para penyelenggara pelaksana putusan pengadilan. Pembentukan kebijakan hukum didasarkan pada cita hukum, cita-cita dan tujuan negara yang termaktub di dalam konstitusi. ${ }^{19}$

Manfaat studi politik hukum di Indonesia yakni dapat mewujudkan cita-cita bangsa sebagaimana yang tertera di dalam landasan ideologi negara yaitu Pancasila dan UUD NRI 1945, karena politik hukum merupakan alat dan sarana yang digunakan oleh pemerintah untuk membentuk sistem hukum nasional. Hal ini sesuai dengan pendapat Mahfud MD yang menjelaskan bahwa politik hukum merupakan legal policy untuk pemberlakuan hukum sehingga dapat mencapai tujuan negara. ${ }^{20}$ Politik hukum diperlukan karena beberapa sebab, antara lain ${ }^{21}$ :

\footnotetext{
${ }^{17}$ C.F.G. Sunaryati Hartono, Politik Hukum Menuju Satu System Hukum Nasional, Bandung, Alumni, 1991 , hal. 1

${ }^{18}$ Bernard L. Tanya Ed. All, Teori Hukum (Strategi tertib Manusia Lintas Ruang dan Generasi), Op. Cit., hal. 103-104.

${ }^{19}$ Moh. Mahfud, Membangun Politik Menegakkan Konstitusi, Op. Cit, hal. 35.

${ }^{20}$ Moh. Mahfud, Loc. Cit.

${ }^{21}$ Moh.Mahfud, Bahan Kuliah Politik Hukum, PDIH UNDIP, 2017, hal. 3
} 
Vol 2, No. (2019): Law, Development \& Justice Review, Mei 2019. e-ISSN: 2655-1942

a. Hukum terkait dengan perkembangan masyarakat. Hukum akan selalu menyertai kehidupan manusia di manapun berada, dan akan berubah sesuai dengan perkembangan manusia.

b. Hukum tidak dalam vakum, bekerjanya hukum mesti dipengaruhi oleh subsistemsubsistem lain, seperti; politik, sosial, ekonomi, teknologi.

c. Roscoe Pound, berpendapat bahwa hukum adalah alat untuk merekayasa sosial masyarakat (law as a tool of social enginering), hukum bisa mengubah kehidupan masyarakat sesuai yang dinginkan oleh hukum. Hal ini berarti bahwa politik hukum dapat bekerjasama dengan ilmu sosial untuk merekayasa masyarakat untuk didayagunakan pada kemajuan dan pengembangan ilmu hukum. ${ }^{22}$

d. Menurut Von Savigny, hukum timbul bukan karena perintah penguasa, tetapi karena perasaan keadilan yang terletak di dalam jiwa bangsa itu. Jiwa bangsa itulah yang menjadi sumber hukum. Karena itu, Savigny mengeluarkan pendapatnya yang amat terkenal bahwa hukum itu tidak dibuat tetapi tumbuh bersama masyarakat.

e. Menurut Philip Nonet dan Philip Selznick, mengatakan bahwa adanya perubahan sosial dan keadilan sosial, membutuhkan tatanan hukum responsif yang menempatkan hukum sebaga sarana respons terhadap ketentuan-ketentuan sosial dan aspirasi publik. Hukum yang sifatnya terbuka, selalu menerima perubahan demi mencapai keadilan dan tujuan hukum. ${ }^{23}$

Berdasarkan penjelasan di atas, dapat dipahami bahwa keberadaan politik hukum memang layak diperlukan karena hukum selalu bersama manusia untuk mengatur ketertiban dan kehidupan manusia, supaya manusia dapat bahagia dan sejahtera. Oleh karena itu bekerjanya hukum tidak sendirian dan membutuhkan faktor lain (politik, sosial, ekonomi, budaya, teknologi) supaya perannya dapat dirasakan oleh masyarakat. Selain itu, keberadaan politik hukum didukung oleh beberapa teori hukum yang menguatkan alasan mengapa politik hukum sangat diperlukan.

\footnotetext{
22 Soetandyo Wignjosoebroto, Tentang Teori, Konsep Dan Paradigma Dalam Kajian Tentang Manusia, Masyarakat Dan Hukumnya, dalam https://soetandyo.wordpress.com/2010/09/18/tentang-teori-konsepdan-paradigma-dalam-kajian-tentang-manusia-masyarakat-dan-hukumnya/. Diunduh, Jumat, 01 September 2017, pukul 22.15. WIB

${ }^{23}$ Philippe Nonet dan Philip Selznick, Hukum Responsif, Bandung, Nusa Media, 2010, hal 89. Bernard L. Tanya, Ed. All, Teori Hukum (Strategi tertib Manusia Lintas Ruang dan Generasi), Op. Cit. hal. 205.
} 
Vol 2, No. (2019): Law, Development \& Justice Review, Mei 2019. e-ISSN: 2655-1942

\section{Implementasi Politik Hukum di Indonesia}

Sebagaimana dijelaskan di atas, bahwa politik hukum adalah arah pembangunan hukum atau pembuatan dan pemilihan hukum yang berpijak pada sistem hukum nasional guna mencapai tujuan dan cita-cita negara. Politik hukum mampu mengarahkan negara dalam mewujudkan cita-citanya untuk menjadi negara yang melindungi hak-hak warga negara dan menjadikan negara mampu mewujudkan kedamaian dan ketertiban dunia. Munculnya politik hukum berlatar belakang dari ${ }^{24}$ :

a. Adanya tuntutan pembaharuan atau penggantian hukum dari jaman penjajah kolonial Belanda menuju ke jaman kemerdekaan pada tanggal 17 Agustus 1945. Proklamasi kemerdekaan telah membawa perubahan bangsa Indonesia pada idealitas dan realitas hukum yang diwujudkan dalam membentukan dan penetapan hukum berdasarkan kesepakatan para pendiri bangsa.

b. Adanya tuntutan perubahan struktur sosial setelah Indonesia merdeka, akan membawa politik hukum yang mengarahkan pada struktur sosial baru. Hal ini menjadikan hukumpun berubah karena fungsinya untuk melayani masyarakat.

c. Adanya tuntutan perubahan tujuan negara dari tujuan penjajah kolonial yang menjajah negara Indonesia menjadi tujuan pemerintah Indonesia yang merdeka. Sebagaimana tercantum dalam Pembukaan UUD NRI 1945 Alenia IV, yang ditetapkan pada tanggal 18 Agustus 1945, sehari setelah kemerdekaan diikrarkan.

d. Kehendak pendiri bangsa yang menuntut adanya konsekuensi untuk merubah hukum positif dan segala ketentuan perundang-undangan yang bertentangan dengan nilai Pancasila.

e. Politik hukum memberikan inspirasi pemerintah untuk membuat dan membentuk hukum sendiri yang sesuai dengan landasan filosofis Pancasila.

f. Adanya semangat pemerintah untuk menyeleksi berlakunya hukum, mana hukum yang masih tetap dipakai karena mengandung nilai universal, dan mana hukum yang tidak bisa dipakai karena bertentangan dengan nilai kandungan Pancasila.

g. Adanya tuntutan reformasi pemerintahan, yang memandang hukum sebagai salah alat untuk menyelesaikan permasalahan negara, sekaligus meluruskan atau merevisi hukum yang bertentangan dengan Pancasila (yudicial review).

\footnotetext{
${ }^{24}$ Moh. Mahfud, Politik Hukum di Indonesia, Op. Cit. hal. 11-2.
} 
Dengan demikian lahirnya politik hukum secara umum sangat dipengaruhi oleh sistem politik hukum di Indonesia yang bertujuan untuk mewujudkan tujuan ideal hukum. Oleh karena itu pembahasan politik hukum nasional di Indonesia, selalu diarahkan dalam upaya mencari, memilih dan menetapkan perundang-undangan yang dijadikan acuan atau alat negara dalam menyelesaikan problem bangsa. Implementasi politik hukum, yang berupa produk hukum, dapat ditemukan di PROLEGNAS (Program Legeslasi Nasional) dan PROLEGDA (Program Legeslasi Daerah), di mana produk hukum tersebut harus berpijak pada kerangka dasar politik hukum, sebagai berikut ${ }^{25}$ :

a. Mengarah pada cita-cita bangsa yakni masyarakat adil dan makmur berdasarkan Pancasila, karena Pancasila adalah falsafah negara yang mengandung nilai-nilai luhur bangsa yang wajib diterapkan pada pembangunan hukum termasuk pada politik hukum. ${ }^{26}$

b. Ditujukan untuk mencapai tujuan negara, yakni ${ }^{27}$ :

1) Melindungi segenap bangsa Indonesia dan seluruh tumpah darah Indonesia

2) Memajukan kesejahteraan umum

3) Mencerdaskan kehidupan bangsa

4) Ikut melaksanankan ketertiban dunia, berdasarkan kemerdekaan, perdamaian abadi dan keadilan sosial.

c. Dipandu oleh nila-nilai yang berasaskan Pancasila sebagai dasar negara, yaitu; ${ }^{28}$

1) Berbasis moral agama (asas Ketuhanan Yang Maha Esa), yang terdapat pada Sila Pertama yakni Ketuhanan Yang Maha Esa

2) Menghargai dan melindungi hak asasi tanpa diskriminasi (asas kemanusiaan), terdapat pada Sila Kedua yakni Kemanusaan yang adil dan beradab.

3) Mempersatukan seluruh unsur bangsa dengan semua katan primordialnya (asas persatuan dan kesatuan), terdapat pada Sila Ketiga yakni Persatuan Indonesia

\footnotetext{
${ }^{25}$ Moh. Mahfud., Membangun Politik Menegakkan Konstitusi, Op. Cit., hal. 16.

${ }^{26}$ Darji Darmodiharjo dan Sidharta, Pokok-Pokok Filsafat Hukum, Apa Dan Bagaimana Filsafat Hukum Indonesia, Jakarta, PT Gramedia Pustaka Utama, 1999, hal. 227.

${ }^{27}$ Pembukaan UUD NKRI 1945 Alenia keempat.

${ }^{28}$ Tjahyo Kumolo, Konsep dan Implementasi Hukum Negara Pancasila dalam Mengatasi Permasalahan Hukum Nasional, Seminar Nasional, 30 September 2017, Gedung Pascasarjana Lantai 6, Semarang, hal. 3
} 
Vol 2, No. (2019): Law, Development \& Justice Review, Mei 2019. e-ISSN: 2655-1942

4) Meletakkan kekuasaan negara di bawah kekuasaan rakyat (asas demokrasi), terdapat dalam Sila Keempat yakni Kerakyatan yang dipimpn oleh hikmat kebijaksanaan dalam permusyawaran perwakilan.

5) Membangun keadilan sosial (asas keadilan), yang terdapat dalam sila kelima yakni Keadilan sosial bagi seluruh rakyat Indonesia.

Kelima sila di atas merupakan satu kesatuan yang tidak bisa dipisahkan, dan sila pertama menjadi bintang penyinar bagi sila kedua, ketiga, keempat dan kelima.

d. Dipandu oleh cita hukum negara yang mengharuskan untuk ${ }^{29}$;

1) Melindungi semua unsur bangsa demi integrasi atau keutuhan bangsa yang mencakup ideologi dan teritori.

2) Mewujudkan keadilan dalam ekonomi dan kemasyarakatan

3) Mewujudkan demokrasi (kedaulatan rakyat) dan nomokrasi (kedaulatan hukum)

4) Menciptakan toleransi hidup beragama berdasar keadaban dan kemanusiaan.

e. Sistem hukum nasional yang diperlukan untuk mencapai tujuan itu dan faktor-faktor yang mempengaruhinya. Sistem hukum yang harus dibangun adalah sistem hukum Pancasila, yakni sistem hukum yang memadukan berbagai nilai kepentingan, nilai sosial dan konsep keadilan ke dalam satu ikatan hukum prismatik, dengan mengambil unsurunsur baiknya, serta meletakkannya ke dalam hubungan keseimbangan, yakni ${ }^{30}$;

1) Keseimbangan antara individualsme dan kolektifitas

2) Keseimbangan antara rechtstaat dan the rule of law

3) Keseimbangan antara hukum sebgai alat untuk memajukan dan hukum sebagai cermin nilai-nilai yang hidup di masyarakat.

4) Keseimbangan antara negara agama dan negara sekuler.

Hukum prismatik yang merupakan sistem hukum berbasis Pancasila, mempunyai karakteristik sebagai berikut :31

1) Konsep kekeluargaan, maksudnya negara menjamin hak-hak individu dan HAM, namun tetap mengedepankan kepentingan nasional.

\footnotetext{
${ }^{29}$ Bernard L. Tanya, Op. Cit., hal. 113. Moh.Mahfud, Konstitusi dan Hukum dalam Konversi Isu, Jakarta, Rajawali Pers, 2010, hal. 38-39.

${ }^{30}$ Moh. Mahfud., Membangun Politik Menegakkan Konstitusi, Op. Cit., hal. 32.

${ }^{31}$ Arief Hidayat, Negara Hukum Pancasila (Suatu Model Ideal Penyelenggaraan Negara Hukum), Prosiding dalam Konggres Pancasila IV, Strategi Pelembagaan Nilai-Nilai Pancasila dalam Menegakkan Konstutusionalitas Indonesia, PSP UGM, Yogyakarta, hal. 60-61.
} 
Vol 2, No. (2019): Law, Development \& Justice Review, Mei 2019. e-ISSN: 2655-1942

2) Konsep keadilan dan kepastian, artinya pemaduan sisi positif dari berbagai sistem hukum, dengan tujuan memberikan kepastian hukum yang berdasarkan nilai keadilan berbasis Pancasila.

3) Konsep religious nation stage, artinya sistem hukum yang berdasarkan kepercayaan kepada Ketuhanan yang Maha Esa, yang memberikan kebebasan dan perlindungan bagi pemeluk agama untuk menjalankan ajarannya sesuai dengan kepercayaannya. Agama yang diakui di Indonesia ada enam, yakni; Islam, Kristen, Katolik, Hindu, Budha, dan Khong Hu Chu.

4) Konsep keterpaduan antara hukum sebagai cermin nilai-nilai yang hidup di masyarakat dan hukum yang mengarahkan masyarakat pada perkembangan hukum yang dicitacitakan.

5) Konsep perekat persatuan, di mana kehadiran Pancasila sebagai perekat untuk mempersatukan bangsa Indonesia yang beragam budaya, adat, agama, suku dan lainnya. Hal ini sesuai dengan asas Bhineka Tunggal Ika, yang artinya meskipun berbedabeda tetapi tetap satu juga.

Berdasarkan penjelasan di atas, dapat dipahami bahwa implementasi politik hukum berupa ditetapkannya perundang-undangan yang digunakan sebagai alat untuk mencapai tujuan negara. Perundangan-undangan tersebut dapat dilihat di PROLEGNAS DAN PROLEGDA. PROLEGNAS merupakan rencana daftar hukum nasional yang akan dibuat setiap 5 tahun, sedangkan PROLEGDA adalah rencana hukum atau aturan yang akan dibuat oleh pemerintah daerah setiap 5 tahun. ${ }^{32}$ Perwujudan perundang-undangan yang ditetapkan oleh pemerintah sebagai implementasi dari politik hukum di atas, tentunya harus sesuai dengan kerangka dasar politik hukum nasional.

\section{SIMPULAN DAN SARAN}

Berdasarkan penjelasan di atas, maka dapat disimpulkan sebagai berikut;

1. Politik hukum adalah arah pembangunan hukum atau pembuatan dan pemilihan hukum yang berpijak pada kebijakan negara untuk membuat dan menetapkan peraturan perundang-undangan guna mencapai cita-cita dan tujuan negara seperti yang terdapat pada pembukaan UUD NRI 194 Alenia IV.

\footnotetext{
${ }^{32}$ Moh.Mahfud, Bahan Kuliah Politik Hukum, Op. Cit., hal. 4.
} 
Vol 2, No. (2019): Law, Development \& Justice Review, Mei 2019. e-ISSN: 2655-1942

2. Implementasi politik hukum berupa ditetapkannya perundang-undangan yang digunakan sebagai alat untuk mencapai tujuan negara, yang sesuai dengan kerangka dasar politik hukum nasional, yang dapat dilihat di PROLEGNAS DAN PROLEGDA. Perwujudan perundang-undangan harus sesuai dengan kerangka dasar politik hukum nasional.

Saran yang layak disampaikan adalah adanya upaya mengimplementasikan politik hukum yang sesuai dengan kerangka dasar politik hukum nasonal, supaya produk hukum yang dihasilkan tidak bertentangan dengan tujuan negara dan cita dasar pembentukan hukum nasonal.

\section{DAFTAR PUSTAKA}

Budiardjo, Miriam, 2009, Dasar-Dasar Ilmu Politik, Jakarta: Gramedia Pustaka Utama. Darmodiharjo, Darji, dan Sidharta, 1999, Pokok-Pokok Filsafat Hukum, Apa dan

Bagaimana Filsafat Hukum Indonesia, Jakarta: PT Gramedia Pustaka Utama.

Hartono, Sunaryati, 1991, Politik Hukum Menuju Satu System Hukum Nasional, Bandung: Alumni.

Hidayat, Arief, 2014, Negara Hukum Pancasila (Suatu Model Ideal Penyelenggaraan Negara Hukum), Prosiding dalam Konggres Pancasila IV, Strategi Pelembagaan NilaiNilai Pancasila dalam Menegakkan Konstutusionalitas Indonesia, PSP UGM: Yogyakarta.

Huijbers, Theo, 2009, Filsafat Hukum, Yogyakarta: PT. Kanisius.

Kumolo, Tjahyo, 2017, Konsep dan Implementasi Hukum Negara Pancasila dalam Mengatasi Permasalahan Hukum Nasional, Seminar Nasional, 30 September 2017, Gedung Pascasarjana Lantai 6, Semarang.

L. Tanya, Bernard, 2011, Politik Hukum, Agenda Kepentingan Bersama, Genta, Yogyakarta: Publishing.

L. Tanya, Bernard, Ed. All, 2010, Teori Hukum (Strategi tertib Manusia Lintas Ruang dan Generasi), Yogyakarta: Genta Publishing.

Mahfud, MD, Moh, 2010, Membangun Politik Menegakkan Konstitusi, Jakarta: Rajawali Pers. 
Vol 2, No. (2019): Law, Development \& Justice Review, Mei 2019. e-ISSN: 2655-1942

2010, Konstitusi dan Hukum dalam Konversi Isu, Jakarta: Rajawali

Pers.

1998, Politik Hukum di Indonesia, Jakarta: LP3ES.

2010, Politik Hukum di Indonesia, Jakarta: Rajawali Pers.

Raharjo, Satjipto, 2000, Ilmu Hukum, Bandung: Citra Aditya Bakti.

Nonet, Philippe, dan Philip Selznick, 2010, Hukum Responsif, Bandung: Nusa Media.

Samekto, Adji, 2015, Pergeseran Pemikiran Hukum dari Era Yunani Menuju Postmodernisme, Jakarta, Konpress.

Soedarto, 1986, Hukum dan Hukum Pidana, Bandung, Alumni.

Wahyono, Padmo, 1986, Indonesia Negara berdasarkan Atas Hukum, Cet II, Jakarta, Ghalia Indonesia.

1991, Menyelisik Proses Terbentuknya Perundang-Undangan, Forum Keadilan, No. 29 April 1991.

W. Ball, Stephen, 2016, Bibliographical Essay / Legal Positivism, Natural Law, and the Hart/Dworkin Debate, Journal of Criminal Justice Ethics, University of California, San

Diego, ISSN: 0731-129X (Print) 1937-5948 (Online) Journal homepage:

http://www.tandfonline.com/loi/rcre20, hal. 68, upload at 29 June 2016, At: 12:35 WIB.

Undang-Undang Negara Republik Indonesia Tahun 1945 
Vol 2, No. (2019): Law, Development \& Justice Review, Mei 2019. e-ISSN: 2655-1942 